\title{
Correlates and Predictors of Health-Related Quality of Life among Patients with COPD: An Integrative Review
}

\author{
Nazih Abu Tabar ${ }^{1,2^{*}}{ }^{\mathbb{D}}$, Jafar Alasad Alshraideh ${ }^{1}$ \\ ${ }^{1}$ School of Nursing, The University of Jordan, Amman, Jordan \\ ${ }^{2}$ Nursing Department, Ministry of Health, Amman, Jordan \\ Email: ^n-tabar@hotmail.com, jalasad@ju.edu.jo
}

How to cite this paper: Tabar, N.A. and Alshraideh, J.A. (2019) Correlates and Predictors of Health-Related Quality of Life among Patients with /COPD: An Integrative Review. Open Journal of Nursing, 9, 1203-1225. https://doi.org/10.4236/ojn.2019.912088

Received: October 25, 2019

Accepted: December 6, 2019

Published: December 9, 2019

Copyright () 2019 by author(s) and Scientific Research Publishing Inc. This work is licensed under the Creative Commons Attribution International License (CC BY 4.0).

http://creativecommons.org/licenses/by/4.0/ (c) (i) Open Access

\begin{abstract}
Background: Health-related quality of life is an important outcome variable with COPD patients. Impaired health-related quality of life among COPD patients is closely related to various factors. There are many factors that predict the HRQoL and the correlation with other important variables. Predictors of health-related quality of life were debatable in the literature. Aim: This review aimed to describe the correlation with HRQoL and to explore the predictors of HRQoL among patients with COPD. Methods: An integrative review method was conducted. A search protocol was conducted using EBSCO, Pubmed, CINAHL, Ovid, ProQuest, Cochrane, and Google Scholar databases up to October 1, 2019. Results: The review results out of 30 articles that discuss the predictors of HRQoL and 22 articles that discuss the HRQoL correlations with other important variables. The HRQoL predictors are classified according to sociodemographic factors and clinical factors, and also, the correlation and prediction of HRQoL with anxiety, fatigue, and uncertainty. The results of this review showed controversies in predictors between the studies. The most retrieved predictors were age, educational level, comorbidities, socioeconomic status, FEV1\% predicted, GOLD stages, and the number of hospitalizations. The variables of anxiety and fatigue were strongly correlated and predicted HRQoL. While funcertainty was not reported as a significant HRQoL predictor. Conclusion: This review provides support about reliable predictors than unreliable one although some predictors still need further research in different races and cultures. Future research is needed to explore whether uncertainty can predict HRQoL among patients with COPD.
\end{abstract}

\section{Keywords}

HRQoL, COPD Integrative Review, Uncertainty, Anxiety, Fatigue 


\section{Introduction}

Health-related quality of life (HRQoL) is an important outcome variable in many chronic diseases that have an impact on different aspects of a person's life. Chronic Obstructive Pulmonary Disease (COPD) is one of those diseases in which HRQoL is affected and becoming a major environmental and public health issue [1]. Globally, COPD is considered a significant cause of mortality and morbidity across the modern world [2] [3]. COPD is likely to increase in the coming years due to higher smoking prevalence, aging populations in many countries, and the spreading of environmental pollutants [4]. This made COPD the fourth leading cause of death and expected to become the third major cause of death by 2030 worldwide [5].

Chronic Obstructive Pulmonary Disease continues to be an important health burden [6]. COPD is a complex, multifaceted disease. It affects patients in many ways and results in significant impairment in their quality of life (QoL) [7]. It has a major impact on personal health status at large and HRQoL in specific. HRQoL was defined as a very broad concept referring to the quality of life that is directly related to health or illness [8]. HRQoL and QoL are used interchangeably [9]. HRQoL is composed of various aspects that involve physical, mental, emotional, and social wellbeing, which is completely different for each patient [10]. Impaired quality of life among COPD patients is closely related to the symptoms of shortness of breath, dyspnea, and impaired physical activities, like fatigue, and mental problems, like anxiety [1] [11] [12]. Therefore, the evaluation of HRQoL is an important outcome measure in assessing patients with COPD which informs about the causes of the burden of this disease and leads to improve patient management and develops policy decisions [13].

Furthermore, COPD is a distressing, difficult, and progressive condition that makes life miserable for many patients [14]. Thereby, COPD leads to a progressive worsening in HRQoL aspects among those patients who are having this disease [15]. Many studies reported an impairment of HRQoL among COPD patients which measured through using generic or specific HRQoL tools [8] [16] [17] [18]. COPD is a complicated and comorbid disease that has many associated risk factors that can contribute to a significant impairment in functional, psychosocial, emotional and economic costs on the individual, community, and health services [1]. The associated factors lead to a gradual deterioration in the HRQoL, such as: severity of disease symptoms, the impact of symptoms on the subsequent reduction in daily activities, non-adherence management, and therapeutic noncompliance and psychosocial effect [6]. The interest in the associated factors contributing to HRQoL among patients with COPD is increasing [10] [19]. The associated factors were classified in to sociodemographic and clinical variables, functional, psychological, and emotional among patients with COPD. Also, these factors are significant in discovering the main factors that predict the worsening in HRQoL level and explaining the correlation of HRQoL with other variables, specifically the level of anxiety, fatigue, uncertainty among those patients. 
The integrative review aimed to identify and summarize relevant kinds of literature which are described HRQoL predictors and correlation of HRQoL with other variables specifically limited to perceived anxiety, level of fatigue and perceived uncertainty in patients with COPD. The findings of this review will contribute in adopting these predictors for updating clinical practice guidelines, institutional policy regarding the routine assessment and clinical intervention options with COPD patients, and improve knowledge among healthcare providers about the potential impact of psychosocial and physiological wellness on the health status of COPD patients. In addition to providing healthcare researchers with needed information that will help them in appraising and discussing the study results according to their study purpose.

\section{Methods}

\subsection{Data Sources and Search Strategies}

The integrative review was conducted to identify studies describe the predictors of HRQoL and correlate HRQoL with other specific variables among COPD patients. The online databases used in the literature review were PubMed, Cumulative Index to Nursing and Allied Health Literature (CINAHL), ProQuest, Medline, Google Scholar, SAGE Journals, Wiley online Library, Science Direct and EBSCOhost, Ovid journals, and Cochrane for systematic review articles. Literature searches were conducted for articles published up to October 1, 2019. The keywords used for searching in the online databases were COPD, pulmonary disease, anxiety, fatigue, uncertainty, HRQoL, QoL, and systematic review, and a combination thereof. The possible combinations of words were used using Boolean operators like AND or OR. Search in PubMed was conducted by utilizing a highly sensitive search filter technique. All the founded articles were screened for inclusion criteria. Each article retrieved in the search was independently assessed by the researcher in double methods. Researchers reviewed the titles and abstracts of each article. If the article indicated potential inclusion, the full-text of the article was assessed using the inclusion criteria. Any disagreement over the eligibility of particular articles was resolved through reviewing the article again in full or consulting another researcher.

\subsection{Inclusion and Exclusion Criteria}

The articles met the following inclusion criteria were considered for full review: 1) discussed and reported at least two predictors of HRQoL or at least the correlations with one of following variables (i.e. anxiety, fatigue, uncertainty); 2) include HRQoL as outcome variable 3) the measurement of HRQoL was reported with valid and reliable tool; and 4) articles were provided in full text and published in English. Although excluding the publications written in another language than English will introduce a language bias, the English language is still generally perceived to be the universal language of science. The papers include overlapping pulmonary diseases like asthma, obstructive sleep apnea (OSA) or 
didn't meet the inclusion criteria were excluded.

\subsection{Process of Identifying the Relevant Studies and Data Extraction}

The potential articles were first screened for their titles and abstracts. Then, the relevant articles were reviewed in full for consideration of inclusion in the current review. The selection was according to fixed inclusion and exclusion criteria. The primary search in PubMed databases retrieved (80059) articles including research articles and systematic reviews and (44) articles through other resources. After combing three specific variables (anxiety, fatigue, and uncertainty) in the same search engine, (569) articles were identified. After removing duplicates (219) articles were identified. (350) records were excluded because they did not meet the inclusion criteria. From the reviewed titles and abstracts, (140) articles met our search criteria and were reviewed in full. Afterward, the selected articles were assessed for eligibility based on their full text. Of these, (52) final articles were selected. The relatively low number of articles was reflected in the scarcity of evidence around the study variables. After an in-depth review of the included articles, results were summarized according to the following two headings: predictors of HRQoL among COPD patients and the correlation between HRQoL and other specific variables. Figure 1 demonstrates a flow chart for the selection of studies included in the literature review.

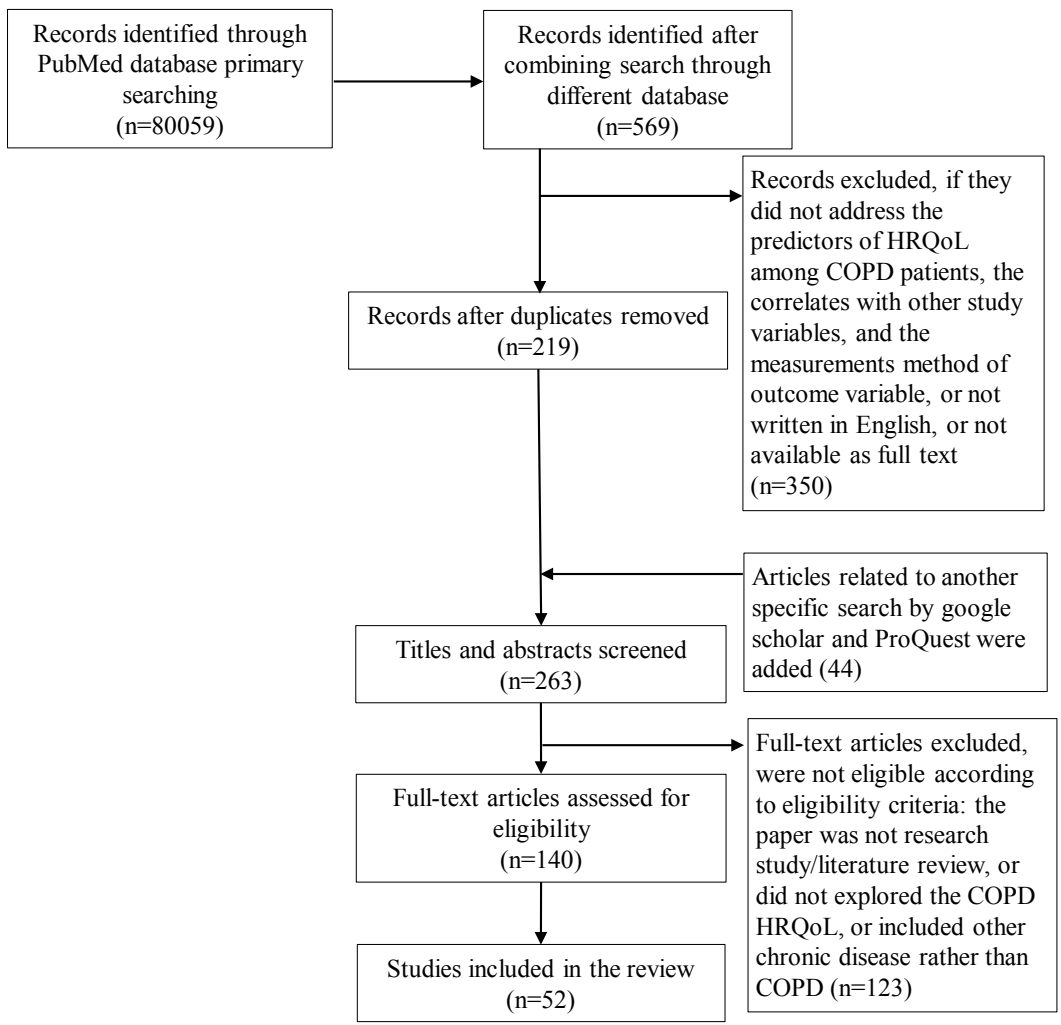

Figure 1. Prisma flow chart for the selection of studies included in the literature review. 


\section{Results}

Health-related quality of life (HRQoL) was recognized as an important outcome when evaluating patients with COPD [20]. The fact that HRQoL is the result of the interaction of physical, psychological, and social factors can justify several predictors of HRQoL among COPD patients which were reported in the literature. These predictive factors were reported into five groups: demographic factors, comorbidity, factors related to the disease, psychological factors, and other related factors. HRQoL was comprised of several domains that involve physical, mental, and social wellbeing which significantly differs for each patient [10]. Impaired quality of life is closely related to shortness of breath, impaired physical activities, and mental problems such as; anxiety [17]. COPD was found clearly correlated with fatigue, anxiety and reduced HRQoL. Therefore, HRQoL should be measured in tools that assess physical, social, and psychological domains. Currently, many HRQoL tools are available. Although there are generic HRQoL tools, which can be used to evaluate HRQoL in general for any population, there are disease-specific tools that can be used in patients with a certain disease experience [21]. So, the recommendation of using a disease-specific tool is needed to cover specific HRQoL aspects and patient-related experiences [22].

In this review, the predictive factors were described into two Tables; Table 1 presents the characteristics of the (30) studies analyzing factors predicting the HRQoL among patients with COPD and Table 2 presents characteristics of (22) studies describing the correlations and predictive factors between HRQoL and other variables limited to (anxiety, fatigue, and uncertainty). So, to address the purpose of this integrative review, the findings were categorized under the following headings; predictors related to sociodemographic and clinical variables and correlate and predictors between HRQoL and other variables.

Table 1. Characteristics of the studies analyzing factors predicting the HRQoL of patients with COPD $(\mathrm{N}=30)$.

\begin{tabular}{|c|c|c|c|c|c|c|}
\hline Author/Date & Study Sample & Study design & $\begin{array}{l}\text { Data Collection } \\
\text { Period }\end{array}$ & $\begin{array}{l}\text { The instrument } \\
\text { used to measure } \\
\text { HRQoL }\end{array}$ & $\begin{array}{l}\text { Predicting } \\
\text { factor of HRQoL }\end{array}$ & $\begin{array}{l}\text { Non predicting } \\
\text { factor of HRQoL }\end{array}$ \\
\hline (Wu et al., 2019) & 154 patients & $\begin{array}{l}\text { A cross-sectional } \\
\text { design }\end{array}$ & $\begin{array}{l}\text { Between Decembe } \\
2016 \text { and } \\
\text { November } 2017\end{array}$ & CCQ & $\begin{array}{l}\text { Age, Smoking status, Disease } \\
\text { duration }\end{array}$ & $\begin{array}{l}\text { Gender, marital status, } \\
\text { employment status, BMI }\end{array}$ \\
\hline $\begin{array}{l}\text { (Shah, Shah, \& } \\
\text { Kachoria, 2019) }\end{array}$ & 60 patients & $\begin{array}{l}\text { A prospective, } \\
\text { cross-sectional } \\
\text { study }\end{array}$ & $\begin{array}{l}\text { From April to } \\
\text { September } 2017\end{array}$ & SGRQ-C & $\begin{array}{l}\text { Age, Nutrition, Smoking } \\
\text { status, Alcohol intake, } \\
\text { Socioeconomic status, } \\
\text { Duration and severity of } \\
\text { the disease, Presence of } \\
\text { comorbidities, Type of COPD } \\
\text { medication used, BMI }\end{array}$ & $\begin{array}{l}\text { Sex, Education level, } \\
\text { Employment status, } \\
\text { Dietary habits }\end{array}$ \\
\hline $\begin{array}{l}\text { (Wytrychiewicz } \\
\text { et al., 2019) }\end{array}$ & 105 patients & $\begin{array}{l}\text { Descriptive } \\
\text { correlational } \\
\text { study }\end{array}$ & NA & $\begin{array}{l}\text { Newley } \\
\text { developed a tool } \\
\text { which assesses } \\
\text { eight aspects of } \\
\text { illness } \\
\text { potentially } \\
\text { affecting QoL }\end{array}$ & Smoking status, BMI & $\begin{array}{l}\text { Sex, Age, Marital status, } \\
\text { Place of residence, } \\
\text { Education, professional } \\
\text { activity, Years since } \\
\text { COPD diagnosis, } \\
\text { Number of } \\
\text { hospitalizations due to } \\
\text { COPD }\end{array}$ \\
\hline
\end{tabular}




\section{Continued}

(Ghilley, Bhadoria, 120 patient \& Pandit, 2018

(Pati et al., 2018) 110 patients

(Gaude \& Desai, 44 patients
2018)

(Farag, Sobh,

Elsawy, \& Fahmy, 200 patients 2018)

(Brandl et al., 206 patients
2018)

(Lee et al., 2017) 1264 patients

(Das, Bam, \&

Ghimire, 2017)

81 patients

(Cheruvu, Odhiambo, Mowls, 16602 patients
Zullo, \& Gudina, 2016)

(Kwon \& Kim, 2016)

(Martinez et al., 2016)

(Sharma \& Joshi, 2015)

40 patients

(Hong et al., 2015) 1178 patients

(Ekici, Bulcun,

Karakoc, Senturk, 62 patients \& Ekici, 2015)

142 COPD

$\begin{aligned} \text { (Xiang et al., 2015) } & \begin{array}{l}\text { outpatients and Case-control } \\ 218 \text { controlled study } \\ \text { COPD }\end{array}\end{aligned}$

May 1,2004 , to April 30, 2005.

A cross-sectional

observational

multicenter 2 years

study

A prospective

patient cohort 1 year and 4

study

months

Descriptive

observational 5 months

cross-sectional

Telephone From the 2011

survey designed and 2012

Cross-sectional Between

survey study 2007-2012

a cross-sectional

analysis of data

in the COPD from

1522 participants participants with ${ }^{\text {NA }}$

COPD in two

cohorts study 2014

Descriptive

correlational

NA
SGRQ-C

FEV1/FVC (\%) ratio

Advanced age, Sex/female,

More than two

comorbidities, Low income,

Family support

NA

FEV1 \% Predicted, New, GOLD

Between December

Prospective 2011 and SGRQ-C

cohort November 2015

A cross-sectionalFrom August 6, hospital-based 2014, to August 7,

A cross-sectionalBetween the year survey analysis of 2007 and 2010

EQ-5D

SGRQ

Short-Form CAT, Number of, (SF-12) Health exacerbations

Survey (years), FEV1\% Predicted, Questionnaire Living alone

Age, Education, No of comorbidities, 6MWD,

Depression level, mMRC

SGRQ-C Smoking status

A newly

developed

tool which

contains four

HRQOL

indicators

EQ-5D

Age, Sex, Severity of COPD,

Diabetes and hypertension comorbidities, Smoking status

Race, Smoking status,

Moderate to severe dyspnea, exacerbation frequency,

Presence of chronic

bronchitis symptoms

56-item QOL Age, Current smoker,

Education level,

questionnaire

Comorbidities, Hospital no of admission last three months,

Need of drugs regularly

Old age, female gender, lower

education level, many

comorbid diseases, severe

airflow obstruction (Gold stage)

FEV1 \% Predicted, mMRC,

Anxiety scores

MOS-SF-12

SGRQ
Marital status, Education,

Religious belief, Life event in

the past year
Age, BMI, Smoke

pack/year, GOLD stage

Occupation, Place of

living

Age, Sex, Smoking, BMI, Socioeconomic status, Occupation type

Age, BMI, GOLD

, Spirometrics staging, BODE index, FEV1/FVC (\%), Smoking pack/year

Age, Female gender, High educational level, Smoking, Number of medications, Disease duration

Sex, BMI, Smoking status, FEV1\% predicted

Age, Sex, Occupation, Education, Medications

Activity limitation, Unmarried, Level of education less than a college degree

Educational level, Income level

Comorbidities, Activity level, Anxiety, and depression

Sex, Marital status, Place of residence, Family type, Work status, Economic status, Duration of COPD, Smoking status

BMI, ever-smoking

Age, BMI, Total number of hospitalizations, Depression score COPD severity, Living with others, Age/year, Sex/male, No of comorbidities, No of hospitalization last year ADLs 
(Bentsen,

Miaskowski, \& 100 patients

Rustøen, 2014)

(Bonsaksen,

Short Form 12,

Haukeland-Parker, 127 patients

Lerdal, \&

Fagermoen, 2014)

(Negi, Sarkar,

Raval, Pandey, \& 126 patients

Das, 2014)

(Raherison et al., 2014)

430 patients

(Abu Hassan, Abd

Aziz, Hassan, \& 117 patients

Hassan, 2014)

(Justine, Tahirah,

\& Mohan, 2013)

100 patients

100 COPD

(Bentsen, Rokne, \&patients and

Wahl, 2013) 3594 general population

(Obaseki, Erhabor,

Awopeju, Obaseki, 50 patients

\& Adewole, 2013)

(Burgel et al.,

2013)

326 patients

(Zamzam, Azab, El

Wahsh, Ragab, \& 40 patients

Allam, 2012)

(Joseph, Pascale, Georges, \& Mirna, patients from 2012)

284 COPD

sample

Cross-sectional

Between October 2009 and CCQ study September 2010

SGRQ

a cross-sectional NA

study

Between January HADS

Cross-sectional 2005 and August SGRQ

2009.

longitudinal

design

2 months after

Between

November 201

and April 2012

SF-36.

Hindi version BMI, FEV1\% predicted, of SGRQ

A multicenter

November 2010 SGRQ-C study

analysis

NA

NA

SGRQ

224 African

American and

(Han et al., 2011) 1049 Caucasian subjects with

Descriptive

design

NA

SGRQ

Survey

(Sundh, Ställberg,

Lisspers,

Montgomery, \& 1548 patients

Janson, 2011)

Abbreviations: HRQoL, Health-Related Quality of Life; QoL, Quality of Life; SGRQ, St George's Respiratory Questionnaire; FEV1\%, Forced Expiratory Volume in One Second; m MRC, Modified Medical Council Research Dyspnea scale; 6MWD, 6-minute walk distance; CAT, COPD Assessment Test; EQ5D, Euro Qol; CCQ, Clinical COPD Questionnaire; MOS SF-36, Medical Outcome Study of Short Form 36; QWB-SA, Self-Administered Quality of Well-Being Scale; MILQ, Multidimensional Index of Life Quality;
Number of

comorbidities, Pain

intensity, Depression

score, Physical functions,

GOLD Spirometrics

staging, FEV1 \%

Predicted

Age, Sex, Education,

Work status, Illness perception Physical activity,

Self-efficacy

Age, Sex, Area of

residence, Smoking

index, Seasonal variation

MRC dyspnea score, Number Gold stage, Age, of treatments, Age, Anxiety, FEV1\% predicted

FEV1/FVC, BOD Index, No of exacerbation

Smoking status, No of hospital admission due to COPD

No of days warded

Dyspnea score

Lung function

COPD stage and severity

Age, Sex, Education level

Breathlessness, Weight loss,

Smoking pack/year

Age, Sex, Smoking status, GOLD stage,

FEV1/FVC \%, BMI

Exacerbation/patient/year,

Dyspnea, Low BMI,

CAD/Comorbidity

Age, Smoking pack/year, Comorbidities, Current smokers, Sex

Smoking index

predicted

Cumulative cigarette dose,

Older age, having at least one education, Female gender, Any COPD severity scoring heart disease, Heating house by diesel, Cumulative waterpipe dose

Pack-year smoking history, predicted, mMRC, The number Race of exacerbations

Educational level, BMI, Heart disease, GOLD stage

Sex, Age, Smoking status, comorbidities smoker in the family, Lower Younger age, Lower FEV 1\% 
Table 2. Study characteristics of correlates and predictors between HRQoL and other variables $(\mathrm{N}=22)$.

\begin{tabular}{|c|c|c|c|c|c|}
\hline $\begin{array}{l}\text { Author/ } \\
\text { Date }\end{array}$ & $\begin{array}{l}\text { Study } \\
\text { Sample }\end{array}$ & $\begin{array}{l}\text { Study } \\
\text { design/ } \\
\text { sampling }\end{array}$ & Study Purpose & $\begin{array}{l}\text { Data } \\
\text { Collection } \\
\text { period }\end{array}$ & $\begin{array}{l}\text { The instrument } \\
\text { used to measure } \\
\text { HRQoL }\end{array}$ \\
\hline $\begin{array}{l}\text { (Ivziku, } \\
\text { Clari, } \\
\text { Piredda, } \\
\text { De Marinis, } \\
\text { \& Matarese, } \\
\text { 2019) }\end{array}$ & 80 dyads & $\begin{array}{l}\text { A cross- } \\
\text { sectional } \\
\text { descriptive } \\
\text { design }\end{array}$ & $\begin{array}{l}\text { To assess the influence of } \\
\text { anxiety and depression on } \\
\text { the physical and mental QoL } \\
\text { in a patient with COPD and } \\
\text { caregiver dyads }\end{array}$ & $\begin{array}{l}11 \text { months } \\
\text { from } \\
\text { November } \\
2016 \text { to } \\
\text { October } \\
2017\end{array}$ & $\begin{array}{l}\text { GAD-7 } \\
\text { Health Survey } \\
\text { (SF-12) }\end{array}$ \\
\hline
\end{tabular}

(Jarab,

Alefishat,

Mukattash, 28

Alzoubi, \& patients

Pinto, 2018)

(Brien et al., 735

2018) patients cross-section al analysis of cohort study

Qualitative To explore patients' views and perceptions regarding group COPD and its impact on their quality of life

To investigate factors associated with poor QoL, focusing on psychological measures potentially amenable to intervention
A

qualitative To explore the unmet

(Quaderi \& 18 method

Hurst, patients and focused

2018) 18 doctors group/ convenience sampling

Qualitative To explore the patient's

(Kouijzer, 20 form Brusse-Keiz inpatient er, \& Bode, and 2018) outpatient

(Stridsman 795 et al., 2018) patients

Population based study needs of patients from both patients and doctors managing COPD

semiperspective on the impact structured interview/ purposive sampling

To evaluate the association between fatigue and health-related quality of life In 2014 HRQoL both among subjects with and without COPD

a crosssectional study/a survey method
To assess the impact of fatigue and dyspnea symptoms on quality of life in individuals with COPD
January DI

2014 to BFI

May 2015 CCQ
A qualitative study by the focused group and four themes emerged

A qualitative study by the focused group and four themes emerged

FACIT-Fatigue

EQ-5D

CAT
This study found that psychological distress affects the QoL of COPD patients and caregivers consistently with prior research that used individual level of analysis and these results confirm the negative impact of anxiety and depression on the caregivers' mental QoL.

In this qualitative study about patients' perspectives regarding COPD and its impacts on HRQoL, the evidence was COPD had a negative physical and psychological impact like anxiety on COPD patients.

The study was evident that psychological factors like anxiety significantly contribute to disease-specific QoL impairment in COPD

This study aimed to explore the psychological impacts as an unmet need of patients that could potentially improve their quality of life from both patients' and doctors' perspectives whose managing patients with COPD. The study results showed most patients with COPD experienced difficulties in their psychosocial and physical functions such as breathlessness, fear, and helplessness that affect QoL and lead to social isolation.

The study findings indicate that patients with COPD perceive the impact of fatigue on their daily lives to be a key factor in decreasing their quality of life

In this population-based study, clinically relevant fatigue was associated with worse HRQoL among subjects with and without COPD when using the clinically useful generic instrument EQ-5D-VAS. Also, among subjects with COPD, clinically relevant fatigue was independently associated with anxiety

The symptoms of fatigue, Dyspnea, and anxiety were moderate to highly correlate with each other, and with HRQoL. Thus, all individuals have an impact on their health-related quality of life. 


\begin{tabular}{|c|c|c|c|c|c|c|}
\hline $\begin{array}{l}\text { (Lim, Kim, } \\
\text { Kim, \& } \\
\text { Kim, 2017) }\end{array}$ & $\begin{array}{l}130 \\
\text { patients }\end{array}$ & $\begin{array}{l}\text { A } \\
\text { descriptive } \\
\text { cross- } \\
\text { sectional } \\
\text { design/ } \\
\text { convenient } \\
\text { sampling }\end{array}$ & $\begin{array}{l}\text { To identify symptom clusters } \\
\text { and the effects on quality of } \\
\text { life (QOL) in patients with } \\
\text { COPD }\end{array}$ & $\begin{array}{l}\text { Between } \\
\text { November } \\
\text { and } \\
\text { December } \\
2014\end{array}$ & $\begin{array}{l}\text { Korean version } \\
\text { of the CAT }\end{array}$ & $\begin{array}{l}\text { Symptom cluster } 1 \text { consisted of dyspnea, } \\
\text { physical functional status, and dry mouth; } \\
\text { symptom cluster } 2 \text { consisted of anxiety and } \\
\text { depression, and symptom cluster } 3 \\
\text { consisted of sleep disturbance and fatigue. } \\
\text { Subgroup cluster analysis showed that } \\
\text { COPD subjects with higher-scoring } \\
\text { symptoms in symptom clusters } 1,2 \text {, and } 3 \\
\text { had significantly poorer QOL. }\end{array}$ \\
\hline $\begin{array}{l}\text { (Pascal, } \\
\text { Trofor, } \\
\text { Lotrean, } \\
\text { Filipeanu, \& } \\
\text { Trofor, } \\
\text { 2017) }\end{array}$ & $\begin{array}{l}60 \\
\text { patients }\end{array}$ & $\begin{array}{l}\text { an } \\
\text { observational } \\
\text { study }\end{array}$ & $\begin{array}{l}\text { To assess anxiety, depression } \\
\text { and panic disorders among } \\
\text { patients diagnosed with } \\
\text { COPD and to investigate } \\
\text { their correlation with disease } \\
\text { severity, QoL as well as } \\
\text { tobacco use }\end{array}$ & $\begin{array}{l}\text { Between } \\
\text { January and } \\
\text { September } \\
2014\end{array}$ & $\begin{array}{l}\text { HADS } \\
\text { CAT }\end{array}$ & $\begin{array}{l}\text { The results indicated associations between } \\
\text { anxiety, depression, panic attacks, and } \\
\text { disease severity, as well as poor quality of } \\
\text { life of patients with COPD, regardless of } \\
\text { their current tobacco use status. }\end{array}$ \\
\hline $\begin{array}{l}\text { (Mewes, } \\
\text { Rief, Kenn, } \\
\text { Ried, \& } \\
\text { Stenzel, } \\
\text { 2016) }\end{array}$ & $\begin{array}{l}502 \\
\text { patients }\end{array}$ & $\begin{array}{l}\text { a } \\
\text { cross-section } \\
\text { al online } \\
\text { survey }\end{array}$ & $\begin{array}{l}\text { To investigate the influence } \\
\text { of psychological factors on } \\
\text { HRQL and disability in } \\
\text { COPD individuals recruited } \\
\text { from the general population. }\end{array}$ & $\begin{array}{l}\text { Between } \\
\text { May and } \\
\text { September } \\
2012\end{array}$ & $\begin{array}{l}\text { Health Survey } \\
\text { (SF-12) } \\
\text { PHQ }\end{array}$ & $\begin{array}{l}\text { High depression and anxiety were the } \\
\text { main predictors of low mental HRQoL. } \\
\text { an association was found between strong } \\
\text { emotional reactions to COPD and low } \\
\text { mental HRQoL }\end{array}$ \\
\hline $\begin{array}{l}\text { (Martinez } \\
\text { et al., 2016) }\end{array}$ & $\begin{array}{l}4097 \\
\text { patients }\end{array}$ & $\begin{array}{l}\text { a } \\
\text { cross-section } \\
\text { al analysis of } \\
\text { data from } \\
\text { participants } \\
\text { with COPD } \\
\text { in two } \\
\text { cohorts }\end{array}$ & $\begin{array}{l}\text { To explore factors associated } \\
\text { with age-related differences } \\
\text { in HRQL in COPD. }\end{array}$ & NA & SGRQ & $\begin{array}{l}\text { Anxiety was associated with change and } \\
\text { predicting HRQoL }\end{array}$ \\
\hline $\begin{array}{l}\text { (Paap, } \\
\text { Bode, } \\
\text { Lenferink, } \\
\text { Terwee, \& } \\
\text { van der } \\
\text { Palen, 2015) }\end{array}$ & $\begin{array}{l}13 \text { Health } \\
\text { care } \\
\text { professionals }\end{array}$ & $\begin{array}{l}\text { Qualitative } \\
\text { study/face to } \\
\text { face } \\
\text { interview }\end{array}$ & $\begin{array}{l}\text { To identify which domains } \\
\text { of HRQoL are most } \\
\text { important for patients with } \\
\text { COPD from the perspective } \\
\text { of healthcare professionals }\end{array}$ & $\begin{array}{l}\text { From July } \\
\text { through } \\
\text { December } \\
2013\end{array}$ & $\begin{array}{l}\text { Seven main } \\
\text { themes emerged } \\
\text { from the analysis } \\
\text { of the open } \\
\text { question }\end{array}$ & $\begin{array}{l}\text { The study findings report the most } \\
\text { frequently selected Patient-Reported } \\
\text { Outcomes Measures (PROMs) domains } \\
\text { which are fatigue, physical function, } \\
\text { emotional support, anxiety, and } \\
\text { depression that showed the most } \\
\text { important domains to measure and } \\
\text { associated with HRQoL among patients } \\
\text { with COPD. }\end{array}$ \\
\hline $\begin{array}{l}\text { (Mehta et } \\
\text { al., 2014) }\end{array}$ & $\begin{array}{l}59 \\
\text { patients }\end{array}$ & $\begin{array}{l}\text { a } \\
\text { cross-section } \\
\text { al study }\end{array}$ & $\begin{array}{l}\text { To study the association of } \\
\text { psychiatric co-morbidities } \\
\text { and QoL with the severity of } \\
\text { COPD. }\end{array}$ & $\begin{array}{l}\text { Between } \\
\text { September } \\
\text { and } \\
\text { November } \\
2013\end{array}$ & $\begin{array}{l}\text { HADS } \\
\text { SGRQ }\end{array}$ & $\begin{array}{l}\text { Patients with depression and anxiety } \\
\text { disorders were likely to have a poorer } \\
\text { quality of life represented by higher SGRQ } \\
\text { scores. Also, patients with severe } \\
\text { respiratory symptoms are more likely to } \\
\text { suffer from anxiety disorders and } \\
\text { depression and have a poorer quality of } \\
\text { life. }\end{array}$ \\
\hline $\begin{array}{l}\text { (Miyazaki } \\
\text { et al., 2014) }\end{array}$ & $\begin{array}{l}336 \text { COPD } \\
\text { patients and } \\
67 \\
\text { non-COPD } \\
\text { subjects }\end{array}$ & $\begin{array}{l}\text { an } \\
\text { observational } \\
\text { study }\end{array}$ & $\begin{array}{l}\text { To investigate comorbid } \\
\text { factors that may contribute } \\
\text { to high CAT scores }\end{array}$ & $\begin{array}{l}\text { Between } \\
\text { April } 2010 \\
\text { and } \\
\text { December } \\
2012\end{array}$ & $\begin{array}{l}\text { SF-36 version } 2 \\
\text { CAT } \\
\text { SGRQ } \\
\text { HADS }\end{array}$ & $\begin{array}{l}\text { There is a significant-good correlation with } \\
\text { the SGRQ total score, all components of } \\
\text { the SF- } 36 \text {, and CAT score with anxiety in } \\
\text { the COPD patients. }\end{array}$ \\
\hline $\begin{array}{l}\text { (Al-Gamal, } \\
2014)\end{array}$ & $\begin{array}{l}67 \\
\text { patients and } \\
\text { spouses }\end{array}$ & $\begin{array}{l}\text { a cross- } \\
\text { sectional, } \\
\text { descriptive, } \\
\text { correlational } \\
\text { design/ } \\
\text { interview }\end{array}$ & $\begin{array}{l}\text { To examine the relationships } \\
\text { between anxiety, depression, } \\
\text { and QoL of both Jordanian } \\
\text { patients with COPD and } \\
\text { their spouses }\end{array}$ & in 2011 & $\begin{array}{l}\text { QLI } \\
\text { HADS }\end{array}$ & $\begin{array}{l}\text { There was a significant negative correlation } \\
\text { between total patient QoL scores and } \\
\text { depression subscale score and anxiety } \\
\text { sub-scale This indicated that patients with } \\
\text { high psychological distress reported poor } \\
\text { QoL. }\end{array}$ \\
\hline
\end{tabular}




\begin{tabular}{|c|c|c|c|c|c|c|}
\hline $\begin{array}{l}\text { (Burgel et } \\
\text { al., 2013) }\end{array}$ & $\begin{array}{l}326 \\
\text { patients }\end{array}$ & $\begin{array}{l}\text { a } \\
\text { cross-section } \\
\text { al analysis }\end{array}$ & $\begin{array}{l}\text { To evaluate the independent } \\
\text { contribution of } \\
\text { comorbidities including } \\
\text { mood disorders, metabolic } \\
\text { and cardiovascular } \\
\text { comorbidities to SGRQ } \\
\text { scores }\end{array}$ & $\begin{array}{l}\text { Between } \\
\text { January } \\
2005 \text { and } \\
\text { August } \\
2009 .\end{array}$ & $\begin{array}{l}\text { HADS } \\
\text { SGRQ }\end{array}$ & $\begin{array}{l}\text { The univariate data in this study indicated } \\
\text { that COPD subjects with anxiety or } \\
\text { depression had worse HRQoL }\end{array}$ \\
\hline $\begin{array}{l}\text { (Hoth et al., } \\
\text { 2013) }\end{array}$ & $\begin{array}{l}407 \\
\text { patients }\end{array}$ & $\begin{array}{l}\text { Survey } \\
\text { study/online } \\
\text { survey }\end{array}$ & $\begin{array}{l}\text { The primary objective was to } \\
\text { determine whether } \\
\text { ambiguity or complexity has } \\
\text { a stronger impact on } \\
\text { depressive symptoms, } \\
\text { anxiety, quality of life, and } \\
\text { breathlessness. }\end{array}$ & NA & $\begin{array}{l}\text { MUIS } \\
\text { HADS } \\
\text { SGRQ }\end{array}$ & $\begin{array}{l}\text { Uncertainty about physical symptoms } \\
\text { which is ambiguity consistently predicted } \\
\text { depression, anxiety, quality of life, and } \\
\text { breathlessness over a two-year period } \\
\text { among individuals with COPD while } \\
\text { uncertainty about treatment and the } \\
\text { healthcare system which is complexity did } \\
\text { not have an independent effect on any of } \\
\text { the previous outcome variables. }\end{array}$ \\
\hline $\begin{array}{l}\text { (Lou et al., } \\
\text { 2012) }\end{array}$ & $\begin{array}{l}1100 \\
\text { patients }\end{array}$ & $\begin{array}{l}\text { A } \\
\text { case-controll } \\
\text { ed study/A } \\
\text { cluster- } \\
\text { randomized } \\
\text { sampling }\end{array}$ & $\begin{array}{l}\text { To assess depression and } \\
\text { anxiety in Chinese patients } \\
\text { with COPD }\end{array}$ & $\begin{array}{l}\text { Between } \\
\text { March and } \\
\text { May } 2008\end{array}$ & $\begin{array}{l}\text { SGRQ } \\
\text { HADS }\end{array}$ & $\begin{array}{l}\text { Patients with COPD who had anxiety } \\
\text { and/or depression had a poorer } \\
\text { health-related quality of life }\end{array}$ \\
\hline $\begin{array}{l}\text { (Jiang \& } \\
\text { He, 2012) }\end{array}$ & $\begin{array}{l}96 \\
\text { patients }\end{array}$ & RCT & $\begin{array}{l}\text { To explore the effects of an } \\
\text { uncertainty management } \\
\text { intervention on uncertainty, } \\
\text { anxiety, depression, and QoL } \\
\text { of COPD outpatients in } \\
\text { China }\end{array}$ & $\begin{array}{l}10 \text {-month } \\
\text { study } \\
\text { duration }\end{array}$ & $\begin{array}{l}\text { MUIS-A } \\
\text { SGRQ } \\
\text { STAI }\end{array}$ & $\begin{array}{l}\text { This study suggests that an uncertainty } \\
\text { management intervention is effective in } \\
\text { improving uncertainty, anxiety, } \\
\text { depression, and quality of life in COPD } \\
\text { outpatients. It is provided the first evidence } \\
\text { that uncertainty management can improve } \\
\text { the QoL of COPD patients }\end{array}$ \\
\hline $\begin{array}{l}\text { (Baltzan et } \\
\text { al., 2011) }\end{array}$ & $\begin{array}{l}251 \\
\text { individuals }\end{array}$ & $\begin{array}{l}\text { observational } \\
\text { study/a } \\
\text { secondary } \\
\text { analysis of } \\
\text { data collected } \\
\text { during a } \\
\text { randomized } \\
\text { clinical trial }\end{array}$ & $\begin{array}{l}\text { To determine whether } \\
\text { patients with high fatigue } \\
\text { differed in their response to } \\
\text { pulmonary rehabilitation } \\
\text { program compared to those } \\
\text { with low reported fatigue } \\
\text { both immediately after the } \\
\text { program and } 1 \text { year after } \\
\text { entry. }\end{array}$ & & $\begin{array}{l}\text { SGRQ } \\
\text { CRQ } \\
6 \mathrm{MWD}\end{array}$ & $\begin{array}{l}\text { In this study patients in both groups are } \\
\text { improved similarly in their dyspnea, the } \\
6 \mathrm{MWD} \text { and endurance time after } \\
\text { introducing a pulmonary rehabilitation } \\
\text { program. However, high-fatigue patients } \\
\text { had greater improvements in both the } \\
\text { CRQ fatigue and the SGRQ scores. thus, } \\
\text { this study suggests that high levels of } \\
\text { fatigue are a common feature in patients } \\
\text { with COPD }\end{array}$ \\
\hline $\begin{array}{l}\text { (Balcells et } \\
\text { al., 2010) }\end{array}$ & 337 patients & $\begin{array}{l}\text { a } \\
\text { cross-section } \\
\text { al analysis/ } \\
\text { convenient } \\
\text { sampling }\end{array}$ & $\begin{array}{l}\text { To evaluate the association } \\
\text { between anxiety and } \\
\text { depressive symptoms and } \\
\text { health-related quality of life } \\
\text { (HRQoL), and to identify the } \\
\text { effect modifiers of this } \\
\text { relationship in patients with } \\
\text { chronic obstructive } \\
\text { pulmonary disease }\end{array}$ & $\begin{array}{l}\text { between } \\
\text { January } \\
2004 \text { and } \\
\text { March } \\
2006 .\end{array}$ & $\begin{array}{l}\text { SGRQ } \\
\text { HADS }\end{array}$ & $\begin{array}{l}\text { This study showed a significant association } \\
\text { between anxiety, depression or both and } \\
\text { reduced HRQOL. }\end{array}$ \\
\hline $\begin{array}{l}\text { (Borge, } \\
\text { Wahl, \& } \\
\text { Moum, } \\
\text { 2010) }\end{array}$ & 154 patients & $\begin{array}{l}\text { a } \\
\text { cross-section } \\
\text { al study }\end{array}$ & $\begin{array}{l}\text { To explore the relationships } \\
\text { between demographic and } \\
\text { clinical variables and the } \\
\text { symptoms of breathlessness, } \\
\text { depression, anxiety, fatigue, } \\
\text { sleeping difficulties and pain } \\
\text { for patients with COPD. }\end{array}$ & $\begin{array}{l}\text { from June } \\
2006 \text { to } \\
\text { December } \\
2007\end{array}$ & $\begin{array}{l}\text { HADS } \\
\text { Lee Fatigue Scale } \\
\text { (LFS) } \\
\text { RQLQ }\end{array}$ & $\begin{array}{l}\text { This study confirms breathlessness is } \\
\text { associated with variables of anxiety and } \\
\text { fatigue which affect the QoL in patients } \\
\text { with COPD. }\end{array}$ \\
\hline
\end{tabular}

Abbreviation: CAT, COPD assessment test; HADS, Hospital Anxiety and Depression Scale; SGRQ, St George's Respiratory Questionnaire; PHQ, Patient Health Questionnaire; RCT, Randomized Clinical Trial; MUIS-A, Mishel's Uncertainty in Illness Scale-Adult version; STAI, State-Trait Anxiety Inventory; QLI, Quality of Life Index; FACIT-Fatigue, Functional Assessment of Chronic Illness-Fatigue; GAD-7, Generalized Anxiety Disorder 7-item scale; RQLQ, Respiratory Quality of Life Questionnaire; BFI, Brief Fatigue Inventory; DI, Dyspnea Inventory; CCQ, Clinical COPD questionnaire; CRQ, Chronic Respiratory Questionnaire. 


\subsection{Predictors Related to Sociodemographic and Clinical Variables}

The correlation between HRQoL and age was discussed in several studies, and the results were controversial. Almost seven studies were reported a positive correlation between age and HRQoL [11] [23]-[28]. The SGRQ-c tool was used to measure the HRQoL primarily and the EQ-5D tool was the second. In addition, a few tools were developed by the study researchers. On the other hand, in SGRQ-c the impact of the score was high indicating more worsening of social function and psychosocial disturbances with aging, this could be clarified by the fact that aging is usually linked with impaired activity, depressive symptoms, and anxiety [17] [29] [30] [31]. On the contrary, nearly twelve studies were found a nonsignificant correlation between age and HRQoL indicating age didn't cause impaired HRQoL among those patients [19] [32]-[42].

The gender was correlated with HRQoL. A huge variation was between studies in predicting the gender correlation with HRQoL. Although many studies were found a correlation between two variables as shown in Table 1 . The female patients had lower scores of HRQoL compared with male patients in the following studies [13] [24] [25] [26] [27]. The following five studies showed no significant correlation or difference between the two variables [16] [23] [33] [36] [43].

The educational level was correlated with impaired HRQoL indicating lower educational levels causing worse HRQoL in four studies [13] [25] [27] [33]. In contrast, five studies were showed no correlation between educational level and better HRQoL according to the type of HRQoL measures that have been utilized in these studies [11] [16] [23] [37] [38].

The comorbidities' status and type of disease as clinical variables were correlated with HRQoL. Moreover, the majority of studies should report more than two diseases to confirm the existence of comorbidities associated with HRQoL. The six studies have reported a correlation indicating the presence of two or more of the following diseases, ischemic heart disease or diabetes, or hypertension [11] [13] [17] [19] [23] [43]. While only two studies confirm the correlation between HRQoL with comorbidities status and types [31] [33]. However, many studies have reported the existence of comorbidities without explaining the type of comorbidities as it is shown in Table 1.

The severity of disease was considered the main factor to evaluate the disease progression and effectiveness of treatment. Sometimes it was linked with medication status and type of medication given to the patients through the course of treatment. The severity indicator factors are FEV1\% predicted, GOLD staging, ABCD Criteria, CAT score, mMRC score, and FEV1/FVC\%. Six studies were reported more than two factors as a predictor regarding the severity of disease [8] [15] [16] [17] [32] [44] while only three studies were reported not more than two factors that non predicting the HRQoL [17] [31] [42] [45]. However, most factors were reported, FEV1\% predicted, FEV1/FVC\%, CAT score, and GOLD stages. 
Furthermore, the duration of disease, a number of hospitalizations, smoking behaviors and packs/year, and effect of weight measured by BMI were other clinical variables which discussed the correlation with HRQoL. Although many studies had confirmed these factors as a predictor, other studies reporting inconsistency with the same variables as not predicting factors as shown in Table 1. Moreover, there were widespread debates about the amount of smoke and behavior and it is a correlation with HRQoL. Six studies were reported no correlation between smoking behavior and the smoking indexes with HRQoL [15] [16] [17] [32] [39] [43], while in the following eight studies [11] [23] [27] [28] [38] [44] [46] [47] were reported an existence of correlation between smoking behaviors, smoking index, and HRQoL.

On the other hand, an old study carried out by Wijnhoven and his colleagues [48] reported a controversial result indicating better HRQoL in current smokers. The reasons that patients who are still smoking might be those with a less advanced stage of the disease. While another new study showed current smokers have a poorer quality of life (high total HRQoL score) compared with previous smokers [26].

Recently, new studied variables were discussed as a factors which correlates and predicting HRQoL, such as; type of work which was reported in one study [36], socioeconomic status in two studies [23] [24], nutrition type in one study [23], and the presence of family help and support in one study [24]. In contrast, the following studies were found type of works [23] [24] [25] [28] [37] [40], socioeconomic status [11] [25] [40], and living status [24] [25] [33] [38] not predicting the HRQoL in their population sample. Moreover, one study has reported the factors of areas of residency and seasonal variation effect. These factors were found not predicting the HRQoL [32]. Only one study has reported the correlation with pain, this factor was found not predicting the HRQoL [31].

A few studies have discussed the effectiveness of an interventional program. The 6MWD test is widely used among COPD patients. This test was correlated with lower scores of HRQoL in recent tow studies (best HRQoL) [17] [43]. Regarding the medication use was verified as a predictor of HRQoL. Shah and colleagues [23], Sharma and Joshi [25], Raherison and colleagues [34] demonstrated that deterioration in HRQoL was seen correlating with the number of prescribed medications, whereas other studies [8] [16] [47] were showed that the patients with the greatest impairment of HRQoL are those who are taking more than one medication, and those contained especially inhaled corticosteroids.

Together, numerous studies identified that lower education levels, more breathlessness, fatigue, lower BMI, anxiety, and depressive symptoms adversely affect the HRQoL. [10] [12] [15] [17] [49] [50]. In conclusion, the most common predictors of HRQoL among COPD patients were age, GOLD severity stage of the disease, dyspnea grade, and the number of exacerbations/hospitalizations. Other predicting factors include comorbidity, sex, body mass index, socioeconomic status, and educational level. 
The Health-related quality of life was measured by using different generic and specific tools including general short-form (SF-12) health survey questionnaire which was utilized in three studies [16] [36] [51], MOS SF 36 was utilized in one study [33], and the specific one such as SGRQ-c was utilized in nine studies [8] [15] [17] [23] [24] [36] [37] [39] [43], EQ-5D was utilized in two studies [11] [13], Clinical COPD Questionnaire (CCQ) was utilized in four studies. [27] [28] [41] [46], and a newly developed one by study researchers was utilized in three studies [25] [26] [38]. The frequently utilized tool was the SGRQ-c through all reported studies. The SGRQ-c is a specific tool to measure the severity and HRQoL among patients with COPD. Out of all reported studies, most of the studies were solely used one tool to measure HRQoL, only two studies were used two types of tools in order to compare the level of HRQoL from two types of measurement and to report if there is a significant difference between each tool [33] [52]. Before it was common to see more than two types of tools were utilized to test HRQoL because of the need to cover all aspects of HRQoL, but now utilizing one specific tool is enough which covered the main aspects of HRQoL.

On the other hand, the majority of the study was utilized observational design in cross-sectional and longitudinal time series. The sample size was adequate the minimum in some studies was not less than 40 participants and the maximum, not more than 2734 participants. However, a few studies such as web-based surveys or prospective studies were failed to report the data collection period as shown in Table 1.

\subsection{Correlates and Predictors between HRQoL and Other Variables}

\subsubsection{Perceived Anxiety and Fatigue}

The patients with COPD experience a wide range of burdens which were represented with several symptoms, such as breathlessness, anxiety, and fatigue. These symptoms affect disease assessment and management. Fatigue was reported to be one of the most common symptoms among patients with COPD [53]. The patients with a chronic disease rated fatigue often as one of the key factors leading to reduced QoL [12]. However, the prevalence rate of fatigue was shown that almost half of all patients experienced abnormal fatigue: $23 \%$ mild and $24 \%$ severe fatigue in a study concerning the severity of fatigue in patients with stable, moderate to severe COPD [54]. While the prevalence rates for anxiety range from $17 \%$ to $51 \%$ [55]. Further, two studies supported that COPD patients have a higher incidence of anxiety $21 \%$ to $96 \%$ compared to $20 \%$ in the general population [50] [56]. Other studies were found that $90 \%$ of patients diagnosed with severe COPD suffered from severe breathing difficulty which was complicated by psychological distress related to anxiety and/or depression. The combination of factors resulted in an increased number of severe symptoms, hospitalization, and hospital mortality [56] [57].

Almost three studies discussed the correlation of HRQoL with fatigue. The qualitative study conducted by Kouijzer and colleagues [12], the authors pointed 
out the purpose of the study was to examine the patient's perspective on COPD-related fatigue, the impact on activity daily life, and possible treatment opportunities to tackle the burden of fatigue. The study results showed the COPD-related fatigue causes a severe, negative impact on the physical, emotional, cognitive and social functioning of all participants. The negative impacts on daily functioning were negatively influenced by the HRQoL of patients leading to a heavy mental burden, decreasing patients' joy in life, and even in some cases their will to live. A qualitative study with face to face interviews was conducted to identify the domains of HRQoL from the perspectives of health care professionals. The study found fatigue and anxiety were the most important aspect correlated with impairment in HRQoL [10]. The two cross-sectional descriptive studies found a high correlation between disease symptoms like dyspnea, breathlessness with anxiety and fatigue which have an impact on the HRQoL among COPD patients [50] [58] [59].

Furthermore, a population-based study of (795) participants. The study was conducted to evaluate the correlation and compare between fatigue and HRQoL among COPD and Non-COPD patients. The study found clinically significant fatigue was correlated with worse HRQoL and independently correlated with anxiety [60]. Moreover, an observational study from secondary collected data was embedded within a randomized trial to test the effectiveness of pulmonary rehabilitation program on the level of activity and fatigue. The study results found that high fatigue patients had a greater improvement in both fatigue score in a chronic respiratory questionnaire and the SGRQ scores which indicate a high level of fatigue cause deterioration in the level of HRQoL with COPD patients [61].

Further studies about the correlation of HRQoL with anxiety, about five cross-sectional studies with an adequate sample size were conducted to evaluate the correlation between HRQoL and anxiety as shown in Table 2. Numerous studies had confirmed the results of COPD patients with anxiety had a poorer HRQoL and anxiety was the predictor of low mental HRQoL score [7] [19] [62]-[67]. Two qualitative studies with a focused group method were conducted. The studies aimed to explore patients' views and perceptions regarding COPD and their impacts on daily living. The results emerged four themes indicating that most patients with COPD experiencing difficulties in their psychosocial like anxiety and physical functions that affect their HRQoL and ultimately lead to social isolation [18].

On the other hand, fatigue was measured by using different tools including HADS were utilized in seven studies [4] [19] [64] [67] [68] [69] [70], STAI was utilized in one study [71], FACIT was utilized in one study [59], GAD-7 was used in two studies [7] [72], LFS was used in one study [50], BFI was used in one study [58]. The most frequently used tool was the HADS among all reported studies. This tool is a generic tool used to test anxiety and depression. Regarding fatigue, the GAD-7 was utilized as the most specific tool that has been used 
among COPD patients.

\subsubsection{Uncertainty among COPD}

Uncertainty is defined as "inability to determine the meaning of illness-related events" [73]. However, if the expectations of health care providers differ from the expectations of patients, further confusion and patient uncertainty may be added [74]. Uncertainty about prognosis and symptoms is fundamental in living with a chronic health condition. COPD is characterized by breathlessness and airflow limitation that is not fully reversible. Thus, treatment focuses on managing symptoms and maintaining the HRQoL. The patients must recognize and appropriately understand their symptoms to take inhaler medications and seek evaluation for appropriate management [68]. There was a scarcity in the studies test a correlation of HRQoL with uncertainty. The old two studies were examined uncertainty among COPD patients based on a sample of (26) hospitalized patients [75] [76]. One more study has tested the effectiveness of a specific intervention to manage uncertainty [71]. In this study, the authors found a reduction in uncertainty and improvement in anxiety, depression, and quality of life among the intervention group.

A relatively recent longitudinal study over two years was used to determine which aspect of illness uncertainty (i.e., ambiguity or complexity) has a significant correlation with psychological and selected clinical outcomes over a two year period among patients with COPD. The study results showed the greater uncertainty is correlated with more symptoms of depression and anxiety and reduced QoL. In addition, it was also correlated with worse physical symptoms (i.e., pain and fatigue) [68]. Further studies are needed to investigate more about the uncertainty concept, and it is a correlation with HRQoL.

\section{Discussion}

The aim of this integrative review was to update, identify, and summarize kinds of literature that described HRQoL predictors and correlation of HRQoL with other variables limited to anxiety, fatigue, and uncertainty in patients with COPD. After a comprehensive search, the authors believe this is the first review conducted to cover the HRQoL correlations with variables of fatigue, anxiety, and uncertainty in specific and identifying between predicting and non predicting factors with HRQoL from (52) studies were included in this review. However, the previous review has described only the factors predicting the HRQoL, it was limited in the scope of articles, keywords of search engines, and searching coverage periods [77]. In the current study, Table 1 "characteristics of the studies analyzing factors predicting the HRQL of patients with COPD" was included to evaluate the predictors of HRQoL across different studies. Table 2 "study characteristics of correlates and predictors between HRQoL and other variables" was included to evaluate the correlation with HRQoL and other important variables. The tables were classified according to sample size, study design, data collection period, sampling methods, and type of tool used to measure 
HRQoL. The two tables have presented a disagreement in the literature about the factors that predicting and non predicting the HRQoL among COPD patients.

The predictor factors were categorized according to factors related to demographic and clinical variables. What is new in this review, some related factors were examined which not discussed before in the literature. The factors were found as predictors of HRQoL such as; patient living status, work status and type, and help and support provider. Although numerous studies have been devoted to studying predictors of HRQoL and correlated factors in recent years among COPD patients, some HRQoL aspects remain unclear and need more investigations. A group of physical, emotional, and psychosocial factors was identified that correlated and altered of HRQoL. In conclusion, there is a discrepancy in the factors predicting and correlated HRQoL among COPD patients within the literature when utilizing specific tools to measure HRQoL.

Furthermore, this review identifies the instruments that had been used for collecting data indicating the SGRQ-c was the most utilized tool in the mentioned studies to measure HRQoL, the HADS to measure the anxiety, and the GAD-7 to measure fatigue, and the MUIS to measure uncertainty. Further, about the correlation with HRQoL, there was a significant correlation between anxiety, fatigue, and HRQoL among COPD patients. The literature still lacks clarity about the correlation of HRQoL with uncertainty among COPD patients. Further researches are needed to verify the validity of the reported correlation between HRQoL and other variables. In addition to a correlation with other sociodemographic and clinical variables to confirm the significant predictors.

Moreover, most of the reported studies have been carried out in developed countries. A few types of research have been carried out in developing countries. Cultural variations, pollution-related exposure, and special behaviors must be considered when disseminating the findings obtained from these studies. Contradicting findings are apparent in certain predictors of HRQoL as shown earlier in the provided tables. Additionally, the correlation with HRQoL was categorized according to correlation with perceived anxiety and fatigue and correlation with uncertainty. On the other hand, the studies included in this review were different in reporting quantitative and qualitative research design, sample size, and data collection methods and time period.

\section{Limitations}

Despite the important integrated findings in this review, the authors suggest that there are some limitations to be acknowledged. Excluding non-English language articles can minimize the chance of accessing some relevant literature. Additionally, most samples included participants from diverse cultural groups, complicating the generalizability of these studies, and making generalizations with respect to each study difficult. Finally, the heterogeneity among the studies in terms of the methodologies used and assessment tools makes it difficult to accu- 
rately compare various aspects of the outcomes reported.

\section{Conclusion}

Health-related quality of life was low among patients with COPD. The HRQoL was decreased with the presence of anxiety and fatigue with COPD. There are many predictors that affect HRQoL with COPD. These predictors need more investigation and evaluation. The evaluation of HRQoL predictors among COPD patients should need to consider the measurement tools of HRQoL. The assessment of physical and psychological factors is important for improving COPD symptoms, preventing the consequent deterioration of HRQoL, and choosing the appropriate treatments. The literature demonstrated that HRQoL among COPD patients is apparent as an issue that needs further investigation from cultural perspectives. Certain predictors still have contradictory findings in the non-empirical literature. This review will expect to help in resolving discrepancies in the existing literature about predictors and correlated factors among COPD patients. It would be valuable to rule out which of these factors remain valid to predict $\mathrm{HRQ}$ L in a specific population and cultures. In clinical practice, screening for anxiety, fatigue, and uncertainty would refer potentially affected patients to specific care facilities for further assessment that may be promising approaches to improve the HRQoL among those patients. The findings from this review should encourage health care providers to explore carefully the predictors during patient history taking and interviews as an aid to help them understand why some patients may not respond to provided care options and why some of them are at high risk to a certain limit. This review will guide health care professionals to understand their patients in a more holistic manner.

\section{Acknowledgements}

The authors thank the School of Nursing, University of Jordan for their support in conducting this review.

\section{Conflicts of Interest}

The authors declare no conflicts of interest regarding the publication of this paper.

\section{References}

[1] GOLD (2019) Global Strategy for the Diagnosis, Management, and Prevention of Chronic Obstructive Pulmonary Disease: 2019 Report.

[2] Sarioglu, N., Hismiogullari, A., Bilen, C. and Erel, F. (2016) Is the COPD Assessment Test (CAT) Effective in Demonstrating the Systemic Inflammation and Other Components in COPD? Revista Portuguesa de Pneumologia (English Edition), 22, 11-17. https://doi.org/10.1016/j.rppnen.2015.08.007

[3] WHO. (2019) COPD: Definition. https://www.who.int/respiratory/copd/definition/en/

[4] Quaderi, S.A. and Hurst, J.R. (2018) The Unmet Global Burden of COPD. Global 
Health, Epidemiology and Genomics, 3, e4. https://doi.org/10.1017/gheg.2018.1

[5] WHO (2015) Projections of Mortality and Causes of Death, 2015 and 2030. The World Health Organization, Geneva, Switzerland.

[6] Ding, B., Small, M., Bergström, G. and Holmgren, U. (2017) COPD Symptom Burden: Impact on Health Care Resource Utilization, and Work and Activity Impairment. International Journal of Chronic Obstructive Pulmonary Disease, 12, 677-689. https://doi.org/10.2147/COPD.S123896

[7] Brien, S.B., Stuart, B., Dickens, A.P., Kendrick, T., Jordan, R.E., Adab, P. and Thomas, M. (2018) Independent Determinants of Disease-Related Quality of Life in COPD-Scope for Nonpharmacologic Interventions? International Journal of Chronic Obstructive Pulmonary Disease, 13, 247-256.

https://doi.org/10.2147/COPD.S152955

[8] Ekici, A., Bulcun, E., Karakoc, T., Senturk, E. and Ekici, M. (2015) Factors Associated with Quality of Life in Subjects with Stable COPD. Respiratory Care, 60, 1585-1591. https://doi.org/10.4187/respcare.03904

[9] Karimi, M. and Brazier, J. (2016) Health, Health-Related Quality of Life, and Quality of Life: What Is the Difference? PharmacoEconomics, 34, 645-649.

https://doi.org/10.1007/s40273-016-0389-9

[10] Paap, M.C.S., Bode, C., Lenferink, L.I.M., Terwee, C.B. and van der Palen, J. (2015) Identifying Key Domains of Health-Related Quality of Life for Patients with Chronic Obstructive Pulmonary Disease: Interviews with Healthcare Professionals. Quality of Life Research, 24, 1351-1367. https://doi.org/10.1007/s11136-014-0860-Z

[11] Kwon, H.-Y. and Kim, E. (2016) Factors Contributing to Quality of Life in COPD Patients in South Korea. International Journal of Chronic Obstructive Pulmonary Disease, 11, 103-109. https://doi.org/10.2147/COPD.S90566

[12] Kouijzer, M., Brusse-Keizer, M. and Bode, C. (2018) COPD-Related Fatigue: Impact on Daily Life and Treatment Opportunities from the Patient's Perspective. Respiratory Medicine, 141, 47-51. https://doi.org/10.1016/j.rmed.2018.06.011

[13] Hong, J.Y., Kim, S.Y., Chung, K.S., Kim, E.Y., Jung, J.Y., Park, M.S. and Kim, Y.S. (2015) Factors Associated with the Quality of Life of Korean COPD Patients as Measured by the EQ-5D. Quality of Life Research, 24, 2549-2558. https://doi.org/10.1007/s11136-015-0979-6

[14] Agusti, A., Bel, E., Thomas, M., Vogelmeier, C., Brusselle, G., Holgate, S. and Vestbo, J. (2016) Treatable Traits: Toward Precision Medicine of Chronic Airway Diseases. European Respiratory Journal, 47, 410-419. https://doi.org/10.1183/13993003.01359-2015

[15] Zamzam, M.A., Azab, N.Y., El Wahsh, R.A., Ragab, A.Z. and Allam, E.M. (2012) Quality of Life in COPD Patients. Egyptian Journal of Chest Diseases and Tuberculosis, 61, 281-289. https://doi.org/10.1016/j.ejcdt.2012.08.012

[16] Brandl, M., Böhmer, M.M., Brandstetter, S., Finger, T., Fischer, W., Pfeifer, M. and Apfelbacher, C. (2018) Factors Associated with Generic Health-Related Quality of Life (HRQOL) in Patients with Chronic Obstructive Pulmonary Disease (COPD): A Cross-Sectional Study. Journal of Thoracic Disease, 10, 766-775. https://doi.org/10.21037/jtd.2018.01.122

[17] Farag, T.S., Sobh, E.S.M., Elsawy, S.B. and Fahmy, B.M. (2018) Evaluation of Health-Related Quality of Life in Patients with Chronic Obstructive Pulmonary Disease. The Egyptian Journal of Bronchology, 12, 288-294. https://doi.org/10.4103/ejb.ejb_11_18

[18] Jarab, A., Alefishat, E., Mukattash, T., Alzoubi, K. and Pinto, S. (2018) Patients' 
Perspective of the Impact of COPD on Quality of Life: A Focus Group Study for Patients with COPD. International Journal of Clinical Pharmacy, 40, 573-579. https://doi.org/10.1007/s11096-018-0614-Z

[19] Burgel, P.-R., Escamilla, R., Perez, T., Carré, P., Caillaud, D., Chanez, P., et al. (2013) Impact of Comorbidities on COPD-Specific Health-Related Quality of Life. Respiratory Medicine, 107, 233-241. https://doi.org/10.1016/j.rmed.2012.10.002

[20] Yorgancioglu, A., Havlucu, Y., Celik, P., Dinc, G. and Saka, A. (2010) Relation between Quality of Life and Morbidity and Mortality in COPD Patients: Two-Year Follow-Up Study. COPD: Journal of Chronic Obstructive Pulmonary Disease, 7, 248-253. https://doi.org/10.3109/15412555.2010.496816

[21] Weldam, S.W.M., Schuurmans, M.J., Liu, R. and Lammers, J.-W.J. (2013) Evaluation of Quality of Life Instruments for Use in COPD Care and Research: A Systematic Review. International Journal of Nursing Studies, 50, 688-707.

https://doi.org/10.1016/j.ijnurstu.2012.07.017

[22] Higginson, I.J. and Carr, A.J. (2001) Measuring Quality of Life: Using Quality of Life Measures in the Clinical Setting. BMJ, 322, 1297.

https://doi.org/10.1136/bmj.322.7297.1297

[23] Shah, A.M., Shah, R.B. and Kachoria, S. (2019) Health-Related Quality of Life and Associated Factors in Patients with Chronic Obstructive Pulmonary Disease. Drugs \& Therapy Perspectives, 35, 241-249. https://doi.org/10.1007/s40267-019-00617-9

[24] Pati, S., Swain, S., Patel, S.K., Chauhan, A.S., Panda, N., Mahapatra, P. and Pati, S. (2018) An Assessment of Health-Related Quality of Life among Patients with Chronic Obstructive Pulmonary Diseases Attending a Tertiary Care Hospital in Bhubaneswar City, India. Journal of Family Medicine and Primary Care, 7, 1047-1053.

[25] Sharma, K. and Joshi, S. (2015) Quality of Life of Patients with Chronic Obstructive Pulmonary Disease in Chitwan, Nepal: A Pilot Study Report. International Journal of Medical Science and Public Health, 4, 1235-1241. https://doi.org/10.5455/ijmsph.2015.25022015261

[26] Cheruvu, V.K., Odhiambo, L.A., Mowls, D.S., Zullo, M.D. and Gudina, A.T. (2016) Health-Related Quality of Life in Current Smokers with COPD: Factors Associated with Current Smoking and New Insights into Sex Differences. International Journal of Chronic Obstructive Pulmonary Disease, 11, 2211-2219.

https://doi.org/10.2147/COPD.S106207

[27] Joseph, S., Pascale, S., Georges, K. and Mirna, W. (2012) Cigarette and Waterpipe Smoking Decrease Respiratory Quality of Life in Adults: Results from a National Cross-Sectional Study. Pulmonary Medicine, 2012, Article ID: 868294. https://doi.org/10.1155/2012/868294

[28] Wu, M., Zan, T., Zhao, Q., Ge, S., Li, K. and Li, J. (2019) Symptom Clusters and Health-Related Quality of Life in Chinese Patients with Chronic Obstructive Pulmonary Disease. Western Journal of Nursing Research. https://doi.org/10.1177/0193945919866475

[29] Dignani, L., Toccaceli, A., Lucertini, C., Petrucci, C. and Lancia, L. (2016) Sleep and Quality of Life in People with COPD: A Descriptive-Correlational Study. Clinical Nursing Research, 25, 432-447. https://doi.org/10.1177/1054773815588515

[30] Miravitlles, M., Molina, J., Naberan, K., Cots, J.M., Ros, F. and Llor, C. (2007) Factors Determining the Quality of Life of Patients with COPD in Primary Care. Therapeutic Advances in Respiratory Disease, 1, 85-92. 
https://doi.org/10.1177/1753465807086097

[31] Bentsen, S.B., Miaskowski, C. and Rustøen, T. (2014) Demographic and Clinical Characteristics Associated with Quality of Life in Patients with Chronic Obstructive Pulmonary Disease. Quality of Life Research, 23, 991-998. https://doi.org/10.1007/s11136-013-0515-5

[32] Negi, H., Sarkar, M., Raval, A., Pandey, K. and Das, P. (2014) Health-Related Quality of Life in Patients with Chronic Obstructive Pulmonary Disease in North India. Journal of Postgraduate Medicine, 60, 7-11. https://doi.org/10.4103/0022-3859.128797

[33] Xiang, Y.T., Wong, T.S., Tsoh, J., Ungvari, G.S., Correll, C.U., Sareen, J., Chiu, H.F. (2015) Quality of Life in Older Patients with Chronic Obstructive Pulmonary Disease (COPD) in Hong Kong: A Case-Control Study. Perspectives in Psychiatric Care, 51, 121-127. https://doi.org/10.1111/ppc.12073

[34] Raherison, C., Tillie-Leblond, I., Prudhomme, A., Taillé, C., Biron, E., Nocent-Ejnaini, C. and Ostinelli, J. (2014) Clinical Characteristics and Quality of Life in Women with COPD: An Observational Study. BMC Women's Health, 14, Article No. 31. https://doi.org/10.1186/1472-6874-14-31

[35] Bentsen, S.B., Rokne, B. and Wahl, A.K. (2013) Comparison of Health-Related Quality of Life between Patients with Chronic Obstructive Pulmonary Disease and the General Population. Scandinavian Journal of Caring Sciences, 27, 905-912. https://doi.org/10.1111/scs.12002

[36] Bonsaksen, T., Haukeland-Parker, S., Lerdal, A. and Fagermoen, M.S. (2014) A 1-Year Follow-Up Study Exploring the Associations between Perception of Illness and Health-Related Quality of Life in Persons with Chronic Obstructive Pulmonary Disease. International Journal of Chronic Obstructive Pulmonary Disease, 9, 41-50. https://doi.org/10.2147/COPD.S52700

[37] Vos, T., Abajobir, A.A., Abate, K.H., Abbafati, C., Abbas, K.M., Abd-Allah, F. and Murray, C.J.L. (2017) Global, Regional, and National Incidence, Prevalence, and Years Lived with Disability for 328 Diseases and Injuries for 195 Countries, 1990-2016: A Systematic Analysis for the Global Burden of Disease Study 2016. The Lancet, 390, 1211-1259. https://doi.org/10.1016/S0140-6736(17)32154-2

[38] Wytrychiewicz, K., Pankowski, D., Janowski, K., Bargiel-Matusiewicz, K., Dąbrowski, J. and Fal, A.M. (2019) Smoking Status, Body Mass Index, Health-Related Quality of Life, and Acceptance of Life with Illness in Stable Outpatients with COPD. Frontiers in Psychology, 10, 1526. https://doi.org/10.3389/fpsyg.2019.01526

[39] Ghilley, V.P., Bhadoria, D.P. and Pandit, S. (2018) Correntional Study of the Health-Related Quality of Life, Chronic Obstructive Airway Disease in Northern India, New Delhi. International Journal of Advances in Medicine, 5, 705-709. https://doi.org/10.18203/2349-3933.ijam20182127

[40] Gaude, N.C. and Desai, A.M. (2018) Health Related Quality of Life in COPD Patients: A Cross-Sectional Study. International Journal of Community Medicine and Public Health, 5, 2038-2042. https://doi.org/10.18203/2394-6040.ijcmph20181719

[41] Sundh, J., Ställberg, B., Lisspers, K., Montgomery, S.M. and Janson, C. (2011) Comorbidity, Body Mass Index and Quality of Life in COPD Using the Clinical COPD Questionnaire. COPD: Journal of Chronic Obstructive Pulmonary Disease, 8, 173-181. https://doi.org/10.3109/15412555.2011.560130

[42] Obaseki, D.O., Erhabor, G.E., Awopeju, O.F., Obaseki, J.E. and Adewole, O.O. (2013) Determinants of Health Related Quality of Life in a Sample of Patients with Chronic Obstructive Pulmonary Disease in Nigeria Using the St. George's Respira- 
tory Questionnaire. African Health Sciences, 13, 694-702. https://doi.org/10.4314/ahs.v13i3.25

[43] Lee, H., Jhun, B.W., Cho, J., Yoo, K.H., Lee, J.H., Kim, D.K. and Park, H.Y. (2017) Different Impacts of Respiratory Symptoms and Comorbidities on COPD-Specific Health-Related Quality of Life by COPD Severity. International Journal of Chronic Obstructive Pulmonary Disease, 12, 3301-3310. https://doi.org/10.2147/COPD.S145910

[44] Han, M.K., Curran-Everett, D., Dransfield, M.T., Criner, G.J., Zhang, L., Murphy, J.R. and Regan, E.A. (2011) Racial Differences in Quality of Life in Patients with COPD. Chest, 140, 1169-1176. https://doi.org/10.1378/chest.10-2869

[45] Justine, M., Tahirah, F. and Mohan, V. (2013) Health-Related Quality of Life, Lung Function and Dyspnea Rating in COPD Patients. Monaldi Archives for Chest Disease, 79, 116-120. https://doi.org/10.4081/monaldi.2013.5209

[46] Abu Hassan, H., Abd Aziz, N., Hassan, Y. and Hassan, F. (2014) Does the Duration of Smoking Cessation Have an Impact on Hospital Admission and Health-Related Quality of Life amongst COPD Patients? International Journal of Chronic Obstructive Pulmonary Disease, 9, 493-499. https://doi.org/10.2147/COPD.S56637

[47] Das, S.K., Bam, N. and Ghimire, P. (2017) Health Related Quality of Life (HRQOL) Assessment Using St. George's Respiratory Questionaire in Patients with Stable Chronic Obstructive Pulmonary Disease. Journal of Institute of Medicine, 29, 21-25.

[48] Wijnhoven, H.A., Kriegsman, D.M., Hesselink, A.E., Penninx, B.W. and de Haan, M. (2001) Determinants of Different Dimensions of Disease Severity in Asthma and COPD: Pulmonary Function and Health-Related Quality of Life. Chest, 119, 1034-1042. https://doi.org/10.1378/chest.119.4.1034

[49] Clancy, K., Hallet, C. and Caress, A. (2009) The Meaning of Living with Chronic Obstructive Pulmonary Disease. Journal of Nursing and Healthcare of Chronic Illness, 1, 78-86. https://doi.org/10.1111/j.1365-2702.2008.01005.x

[50] Borge, C.R., Wahl, A.K. and Moum, T. (2010) Association of Breathlessness with Multiple Symptoms in Chronic Obstructive Pulmonary Disease. Journal of Advanced Nursing, 66, 2688-2700. https://doi.org/10.1111/j.1365-2648.2010.05447.x

[51] Moy, M.L., Reilly, J.J., Ries, A.L., Mosenifar, Z., Kaplan, R.M., Lew, R. and Garshick, E. (2009) Multivariate Models of Determinants of Health-Related Quality of Life in Severe Chronic Obstructive Pulmonary Disease. Journal of Rehabilitation Research and Development, 46, 643-654. https://doi.org/10.1682/JRRD.2008.09.0127

[52] Talley, C.H. and Wicks, M.N. (2009) A Pilot Study of the Self-Reported Quality of Life for Patients with Chronic Obstructive Pulmonary Disease. Heart \& Lung, 38, 141-150. https://doi.org/10.1016/j.hrtlng.2008.05.001

[53] Stridsman, C., Lindberg, A. and Skär, L. (2014) Fatigue in Chronic Obstructive Pulmonary Disease: A Qualitative Study of People's Experiences. Scandinavian Journal of Caring Sciences, 28, 130-138. https://doi.org/10.1111/scs.12033

[54] Peters, J.B., Heijdra, Y.F., Daudey, L., Boer, L.M., Molema, J., Dekhuijzen, P.R. and Vercoulen, J.H. (2011) Course of Normal and Abnormal Fatigue in Patients with Chronic Obstructive Pulmonary Disease, and Its Relationship with Domains of Health Status. Patient Education and Counseling, 85, 281-285.

https://doi.org/10.1016/j.pec.2010.08.021

[55] Blinderman, C.D., Homel, P., Billings, J.A., Tennstedt, S. and Portenoy, R.K. (2009) Symptom Distress and Quality of Life in Patients with Advanced Chronic Obstructive Pulmonary Disease. Journal of Pain and Symptom Management, 38, 115-123. 
https://doi.org/10.1016/j.jpainsymman.2008.07.006

[56] Randazzo, V.P. (2015) Anxiety, Depression, Loneliness, Spirituality, and Disease Exacerbation in COPD Patients. Azusa Pacific University, Azusa.

[57] Livermore, N., Sharpe, L. and McKenzie, D. (2010) Prevention of Panic Attacks and Panic Disorder in COPD. European Respiratory Journal, 35, 557-563. https://doi.org/10.1183/09031936.00060309

[58] Chen, Y.W., Camp, P.G., Coxson, H.O., Road, J.D., Guenette, J.A., Hunt, M.A. and Reid, W. D. (2018) A Comparison of Pain, Fatigue, Dyspnea and Their Impact on Quality of Life in Pulmonary Rehabilitation Participants with Chronic Obstructive Pulmonary Disease. COPD: Journal of Chronic Obstructive Pulmonary Disease, 15, 65-72. https://doi.org/10.1080/15412555.2017.1401990

[59] Lim, K.E., Kim, S.R., Kim, H.K. and Kim, S.R. (2017) Symptom Clusters and Quality of Life in Subjects with COPD. Respiratory Care, 62, 1203-1211. https://doi.org/10.4187/respcare.05374

[60] Stridsman, C., Svensson, M., Johansson Strandkvist, V., Hedman, L., Backman, H. and Lindberg, A. (2018) The COPD Assessment Test (CAT) Can Screen for Fatigue among Patients with COPD. Therapeutic Advances in Respiratory Disease, 12. https://doi.org/10.1177/1753466618787380

[61] Baltzan, M.A., Scott, A.S., Wolkove, N., Bailes, S., Bernard, S., Bourbeau, J. and Maltais, F. (2011) Fatigue in COPD: Prevalence and Effect on Outcomes in Pulmonary Rehabilitation. Chronic Respiratory Disease, 8, 119-128. https://doi.org/10.1177/1479972310396737

[62] Mewes, R., Rief, W., Kenn, K., Ried, J. and Stenzel, N. (2016) Psychological Predictors for Health-Related Quality of Life and Disability in Persons with Chronic Obstructive Pulmonary Disease (COPD). Psychology \& Health, 31, 470-486. https://doi.org/10.1080/08870446.2015.1111369

[63] Martinez, C.H., Diaz, A.A., Parulekar, A.D., Rennard, S.I., Kanner, R.E., Hansel, N.N. and Curtis, J.L. (2016) Age-Related Differences in Health-Related Quality of Life in COPD: An Analysis of the COPDGene and SPIROMICS Cohorts. Chest, 149, 927-935. https://doi.org/10.1016/j.chest.2015.11.025

[64] Pascal, O.I., Trofor, A.C., Lotrean, L.M., Filipeanu, D. and Trofor, L. (2017) Depression, Anxiety and Panic Disorders in Chronic Obstructive Pulmonary Disease Patients: Correlations with Tobacco Use, Disease Severity and Quality of Life. Tobacco Induced Diseases, 15, 23. https://doi.org/10.1186/s12971-017-0128-9

[65] Balcells, E., Gea, J., Ferrer, J., Serra, I., Orozco-Levi, M., de Batlle, J. and Garcia-Aymerich, J. (2010) Factors Affecting the Relationship between Psychological Status and Quality of Life in COPD Patients. Health and Quality of Life Outcomes, 8, Article No. 108. https://doi.org/10.1186/1477-7525-8-108

[66] Al-Gamal, E. (2014) Quality of Life, Anxiety and Depression among Patients with Chronic Obstructive Pulmonary Disease and Their Spouses. Issues in Mental Health Nursing, 35, 761-767. https://doi.org/10.3109/01612840.2014.908440

[67] Mehta, J.R., Ratnani, I.J., Dave, J.D., Panchal, B.N., Patel, A.K. and Vala, A.U. (2014) Association of Psychiatric Co-Morbidities and Quality of Life with Severity of Chronic Obstructive Pulmonary Disease. East Asian Archives of Psychiatry, 24, 148-155.

[68] Hoth, K.F., Wamboldt, F.S., Strand, M., Ford, D.W., Sandhaus, R.A., Strange, C. and Holm, K.E. (2013) Prospective Impact of Illness Uncertainty on Outcomes in Chronic Lung Disease. Health Psychology, 32, 1170-1174.

https://doi.org/10.1037/a0032721 
[69] Lou, P., Zhu, Y., Chen, P., Zhang, P., Yu, J., Zhang, N. and Zhao, J. (2012) Prevalence and Correlations with Depression, Anxiety, and Other Features in Outpatients with Chronic Obstructive Pulmonary Disease in China: A Cross-Sectional Case Control Study. BMC Pulmonary Medicine, 12, Article No. 53. https://doi.org/10.1186/1471-2466-12-53

[70] Miyazaki, M., Nakamura, H., Chubachi, S., Sasaki, M., Haraguchi, M., Yoshida, S. and Minematsu, N. (2014) Analysis of Comorbid Factors That Increase the COPD Assessment Test Scores. Respiratory Research, 15, Article No. 13. https://doi.org/10.1186/1465-9921-15-13

[71] Jiang, X. and He, G. (2012) Effects of an Uncertainty Management Intervention on Uncertainty, Anxiety, Depression, and Quality of Life of Chronic Obstructive Pulmonary Disease Outpatients. Research in Nursing \& Health, 35, 409-418. https://doi.org/10.1002/nur.21483

[72] Ivziku, D., Clari, M., Piredda, M., De Marinis, M.G. and Matarese, M. (2019) Anxiety, Depression and Quality of Life in Chronic Obstructive Pulmonary Disease Patients and Caregivers: An Actor-Partner Interdependence Model Analysis. Quality of Life Research, 28, 461-472. https://doi.org/10.1007/s11136-018-2024-Z

[73] Mishel, M.H. (1997) Uncertainty in Acute Illness. Annual Review of Nursing Research, 15, 57-80. https://doi.org/10.1891/0739-6686.15.1.57

[74] Subih, M., Al-Kalaldeh, M., Salami, I., Al-Hadid, L. and Abu-Sharour, L. (2018) Predictors of Uncertainty among Postdischarge Coronary Artery Bypass Graft Patients in Jordan. Journal of Vascular Nursing, 36, 85-90. https://doi.org/10.1016/j.jvn.2017.11.001

[75] Small, S. and Graydon, J. (1992) Perceived Uncertainty, Physical Symptoms, and Negative Mood in Hospitalized Patients with Chronic Obstructive Pulmonary Disease. Heart \& Lung, 21, 568-574.

[76] Small, S.P. and Graydon, J.E. (1993) Uncertainty in Hospitalized Patients with Chronic Obstructive Pulmonary Disease. International Journal of Nursing Studies, 30, 239-246. https://doi.org/10.1016/0020-7489(93)90034-R

[77] Mallouli, M., Dardouri, M., Ajmi, T., Mtiraoui, A., Ben Dhiab, M. and Zedini, C. (2017) Factors Determining the Quality of Life of Patients with COPD: A Review. Clinical Pulmonary Medicine, 24, 227-231. https://doi.org/10.1097/CPM.0000000000000222 